neofilolog

Czasopismo Polskiego Towarzystwa Neofilologicznego

ISSN 1429-2173, elSSN 2545-3971, 2021, NR 57/2, 295-310

http://dx.doi.org/10.14746/n.2021.57.2.9

http://poltowneo.org/

Katarzyna Barbara Tymoszuk

Uniwersytet M arii Curie-Skłodowskiej w Lublinie https://orcid.org/0000-0001-7801-200X katarzyna.tymoszuk@umcs.pl

\title{
Przedyskutujmy to na forum - czyli o zdalnym rozwijaniu wybranych elementów kompetencji translacyjnej
}

\section{Let's discuss it on the forum - remote development of selected elements of translation competence}

The article presents findings of the research into the use of discussion forums in remote learning. This tool was used in a series of academic classes aimed at developing selected elements of translation competence. The paper begins with a discussion of the notion of translation competence and its components, followed by a presentation of didactic objectives formulated for the presented series of classes with full-time teaching in mind, the level of knowledge and skills of the course participants, the degree of realization of the didactic objectives in remote teaching, and conclusions.

Keywords: translation didactics, LSP didactics, translation competence, remote teaching, discussion forum internet tools for teachers

Słowa kluczowe: dydaktyka translacji, dydaktyka języków specjalistycznych, kompetencja translacyjna, zdalne formy nauczania, forum dyskusyjne, narzędzia internetowe w nauczaniu

\section{Wstęp}

Spowodowana pandemią koronawirusa nagła konieczność realizacji w formie zdalnej celów dydaktycznych wytyczonych z myślą o nauczaniu stacjonarnym postawiła dydaktyków na wszystkich poziomach kształcenia, w tym nauczycieli 
akademickich, przed koniecznością dokonania szybkich i często rew olucyjnych zmian w stosowanych przez siebie tradycyjnych, sprawdzonych i doskonalonych przez lata metodach i narzędziach dydaktycznych. Chociaż większość z uczących starała się możliwie szybko dostosować do nowych realiów i prowadzić zajęcia zdalne na poziomie zbliżonym do zajęć prowadzonych w trybie stacjonarnym, to jednak najczęściej słyszy się krytyczne głosy dotyczące skutków nauczania na odległość. Są one tym głośniejsze w środowisku neofilologicznym, gdyż powszechnie wiadomo, że nauka języków obcych na wszystkich poziomach zaawansowania bazuje w głównej mierze na aktywnym wykorzystywaniu nabytych i rozwijaniu nowych sprawności językowych w bezpośredniej komunikacji. Jednak konieczność wyjścia z dydaktycznej „strefy komfortu” i sięgnięcia po nowe, nieznane, bądź mniej popularne formy dydaktyczne w wielu przypadkach okazała się szansą dostrzeżenia w nich potencjału, dzięki któremu być może znajdą one stałe zastosowanie w nauczaniu również po powrocie do stacjonarnych form edukacji. Celem tego artykułu jest przedstawienie obserwacji dotyczących pozytywnych skutków wykorzystania w zdalnym nauczaniu popularnej formy komunikacji internetowej, jaką jest forum dyskusyjne. Narzędzie to zastosowano w ramach cyklu zajęć akademickich, których celem było rozwijanie wybranych elementów kompetencji translacyjnej.

Samo pojęcie kompetencji translacyjnej to termin nadrzędny dla całego kompleksu sprawności, wiedzy i umiejętności stanowiących wyposażenie mentalne tłumacza. Z tego względu na wstępie niezbędna będzie prezentacja wszystkich elementów konstytuujących kompetencję translacyjną, a następnie dopiero sprecyzowanie, które z nich miały znaleźć się w centrum zajęć. W polskiej translatoryce ponadto zgodnie wysuwane są postulaty, aby nabywanie kompetencji translacyjnej odbywało się w ramach całościowo zaplanowanych, ugruntowanych teoretycznie i wystandaryzowanych programów studiów tłumaczeniowych (żmudzki, 2010). W odniesieniu do tego postulatu, celem uzasadnienia podjęcia tematyki translacyjnej na studiach neofilologicznych niewyprofilowanych translatorycznie, w kolejnej części tekstu zostanie scharakteryzowana grupa uczestników zajęć pod względem ich wcześniejszego, językowego i specjalistycznego przygotowania oraz motywacji do rozwijania wybranych elementów kompetencji tłumaczeniowej, a także możliwości dotyczących ewentualnego dalszego nabywania wiedzy i umiejętności konstytuujących pełną kompetencję translacyjną. W dalszej części artykułu scharakteryzuję uwarunkowania techniczne, organizację pracy z wykorzystaniem forum dyskusyjnego oraz poszczególne etapy realizacji postawionych celów dydaktycznych. W końcowej części tekstu omówiony zostanie stopień realizacji celów dydaktycznych, sformułowano też wnioski dotyczące pozytywnych aspektów wykorzystania forum jako narzędzia dydaktycznego. 


\section{Kompetencja translatorska i jej elementy}

Celem dydaktyki translacji, w jej uzualnym rozumieniu jako praktyki nauczania tłumaczenia ${ }^{1}$ (M archwiński, 2010: 339) jest rozwijanie kompetencji translatorskiej. W złożonym układzie interlingwalnej komunikacji pośredniczonej, czyli układzie translacyjnym (Grucza 1993: 161) to tłumacz i jego wyposażenie mentalne, stanowią centralny i niezbywalny element warunkujący powodzenie tej komunikacji, tj. zaistnienie u odbiorców docelowych efektu komunikacyjnego założonego przez nadawcę prymarnego. Kompetencja translacyjna jest przy tym pojęciem złożonym i w związku z nieustanną modyfikacją specyfiki i form pracy tłumaczy (uwarunkowaną np. rozwojem technologii informacyjnych), wymagającym ciągłego redefiniowania (zob. m.in. Grucza, 1981; Marchwiński, 1992; Nord, 1988; Kautz, 2000; Pöchhacker, 2001; Pym, 2003; Hejwowski, 2004; Kelly, 2005; Way, 2008; Małgorzewicz, 2012, 2014; Kościałkowska-Okońska 2013). Bezspornym pozostaje fakt, iż jako suma określonych cech, wiedzy i umiejętności powstaje ona niejako wskutek „nadbudowania” pewnych elementów na istniejącym już wyposażeniu mentalnym danej osoby. Hansen (1998), Resch (1998) i Witte (1998) mówią o sumie kompetencji tłumaczeniowej, socjalnej, kulturowej, interkulturowej i komunikacyjnej, uwarunkowanej posiadaniem, a zatem w pewien sposób „nadbudowanej” na konkretnej wiedzy i umiejętnościach w zakresie języka ojczystego i obcego (zob. Hansen, 1998, Resch 1998, Witte, 1998). Również według Gruczy (2008) dla zaistnienia pełnej kompetencji translatorskiej w sferze wiedzy i umiejętności konkretnej osoby, obok kompetencji komunikacyjnej osoby dwujęzycznej, którą charakteryzuje określona naturalna kompetencja translacyjna, niezbędna jest swego rodzaju „wartość dodana". Wartość tę należy rozumieć jako sumę praktycznej kompetencji translacyjnej oraz kognitywnej kompetencji translatorycznej. Pierwsza z nich to szereg świadomie i celowo wypracowanych reguł i umiejętności translacyjnych, druga - określona wiedza specjalistyczna w zakresie teorii translacji.

Program akademickich studiów magisterskich European Master's in Translation (dalej: EM T) Dyrekcji Generalnej ds. Tłumaczeń Pisemnych Komisji Europejskiej (Toudic, Krause, 2017)2 ${ }^{2}$, definiuje kompetencję translacyjną nabywaną w procesie studiów i rozwijaną nieustannie również po ich ukończeniu, jako sumę kompetencji, wiedzy i umiejętności nadbudowanych na ogólnej kompetencji językowej oraz kulturowej. Dopiero na tym gruncie można rozpocząć

\footnotetext{
${ }^{1}$ Według M archwińskiego (2010: 399), pojęcie to zasadniczo odnosi się bowiem do teoretycznej nauki o metodach nauczania i uczenia się przekładu.

2 Podobnie realizowany na wybranych uczelniach w krajach członkowskich oraz w Polsce i kompatybilny z Europejskimi Ramami Kwalifikacji.
} 
kształtowanie kolejnych elementów, stanowiących wspomnianą wartość dodaną tłumacza profesjonalnego w stosunku do osób dwujęzycznych. Według programu EMT elementy te usytuowane są w pięciu głównych obszarach:

- kompetencji translacyjnej, obejmującej kompetencje: strategiczną, metodologiczną oraz tematyczną (są one niezbędne na wszystkich etapach procesu translacji, począwszy od umiejętności analizy materiału przed przyjęciem zlecenia, poprzez świadome stosowanie strategii translacyjnych adekwatne do interlingwalnych, intertekstualnych, technicznych i interkulturowych uwarunkowań tekstu wyjściowego, a skończywszy na rozumieniu i opanowaniu strategii kontroli jakości i używaniu w tym celu odpowiednich narzędzi i technik);

- $\quad$ kompetencji w zakresie korzystania z technologii wspierających procesy tłumaczenia pisemnego oraz ustnego, a także umiejętnego wykorzystywania możliwości, jakie daje tłumaczenie maszynowe;

- $\quad$ kompetencji personalnej i interpersonalnej, a zatem tak zwanych kompetencji miękkich (pozwalających zwiększyć zdolności adaptacyjne przyszłych absolwentów), takich jak umiejętne zarządzanie miejscem i czasem pracy, stresem, praca w zespole czy świadomość konieczności stałego podnoszenia swoich kompetencji;

- $\quad$ kompetencji usługowej, w skład której wchodzą m.in. wiedza dotycząca społecznej pozycji tłumacza, zdolność dostosowania się do potrzeb rynku, umiejętność nawiązywania oraz utrzymywania kontaktów z potencjalnymi zleceniodawcami, a także negocjowania, rozpoznania wymagań, celów oraz zamiarów potencjalnych i faktycznych klientów, zdolność wyceny własnych ofert i usług, dotrzymywanie terminów i zobowiązań, znajomość norm i standardów dotyczących usług tłumaczeniowych.

Rozwijanie pełnej kompetencji translacyjnej, rozumianej jako suma mniejszych kompetencji konstytuowanych na gruncie niezbędnego przygotowania językowego i kulturowego, realizowane jest w dydaktyce akademickiej przede wszystkim na kierunkach translatorycznych w ramach lingwistyki stosowanej, na specjalizacjach translatorycznych studiów neofilologicznych czy też różnych formach studiów i kursów podyplomowych (zob. Żmudzki 2010; Małgorzewicz 2019). Nie oznacza to jednak braku możliwości realizowania wybranych treści o charakterze translatorycznym również w ramach kierunków neofilologicznych nieposiadających specjalizacji tłumaczeniowych. Zajęcia takie można potraktować jako przygotowanie do przyszłego rozwijania kompetencji translacyjnej w ramach studiów podyplomowych lub jako swego rodzaju warsztaty orientacyjne, które umożliwią studentom filologii pierwsze kontakty ze specyfiką przekładu pisemnego i ustnego, pozwolą na określenie 
Przedyskutujmy to na forum - czyli o zdalnym rozwijaniu wybranych elementów...

własnych predyspozycji do wykorzystywania jednej z dwóch podstawowych form translacji ${ }^{3}$, bądź też chęci pracy w charakterze tłumacza w ogóle. W takim właśnie charakterze, na prośbę grupy docelowej, zaplanowano cele i treści omówionego poniżej cyklu zajęć.

\section{Cele określone dla zajęć stacjonarnych}

Kurs akademicki Języki specjalistyczne - warsztaty jest stałym i powtarzalnym cyklicznie elementem programu dziennych uzupełniających studiów magisterskich na kierunku germanistyka Uniwersytetu Marii Curie-Skłodowskiej w Lublinie w ramach specjalności specjal istyczny język niemiecki. Składa się z 60 godzin i obejmuje drugi i trzeci semestr dwuletniego cyklu. Podjęcie treści translatorycznych w ramach zajęć nie stanowi zatem sytuacji jednorazowej, lecz miało miejsce również we wcześniejszych cyklach akademickich i uzasadnione jest wspominanymi wyżej oczekiwaniami studentów względem zajęć, sygnalizowanymi przez nich niebezpośrednio $^{4}$, a także wprost podczas pierwszego semestru studiów. Możliwość realizacji tych postulatów uwarunkowana była posiadaniem przez studentów niezbędnego wyposażenia mentalnego, stanowiącego podstawę dla rozwijania „wartości dodanej" w postaci elementów kompetencji translacyjnej. Wszystkie osoby tworzące 22osobową grupę konwersatoryjnąjako absolwenci studiów licencjackich na kierunku germanistyka UM CS oraz KUL, spełniały ten warunek. W programach studiów germanistycznych I stopnia na obu uniwersytetach obok zajęć rozwijających wszystkie sprawności językowe przynajmniej do poziomu B2, zawarte są także wykłady i konwersatoria dotyczące aspektów literaturo-, kulturo- oraz realioznawczych, co pozwala przyjąć, że uczestnicy zajęć posiadali kompetencją językową oraz kulturową na poziomie wystarczającym dla podjęcia wspomnianych działań dydaktycznych. Ponadto w ramach realizowanej specjalizacji na studiach II stopnia w semestrze poprzedzającym cykl, słuchacze uczestniczyli w wykładach i warsztatach dotyczących specyfiki języków specjalistycznych, w następstwie czego znali uwarunkowania ich funkcjonowania, a także ich leksykalne, syntaktyczne i tekstualne wyróżniki. Oznacza to, iż dysponowali oni również częściowo ukonstytuowaną kompetencją specjalistyczną, wymagającą jednak dalszego rozwijania.

${ }^{3}$ Jak wiadomo tłumaczenie ustne i tłumaczenie pisemne to dwie zupełnie różne formy translacji, wymagające od wykonujących je osób odmiennych kompetencji, sposobów pracy, temperamentów i cech osobowościowych. 0 różnicach między tłumaczeniem ustnym a tłumaczeniem pisemnym bardzo szczegółowo pisał na przykład Kautz (2000: 288).

${ }^{44}$ Chęć rozwijania kompetencji translacyjnej wynikała między innymi z prac pisemnych i wypowiedzi studentów na zajęciach Praktyczna nauka języka niemieckiego oraz na innych - jednym z najczęściej wymienianych zawodów, który planowali podjąć w przyszłości, był zawód tłumacza pisemnego bądź ustnego. 
W odniesieniu do poziomu wiedzy i umiejętności studentów w obszarach kompetencji językowej, kulturowej i specjalistycznej sprecyzowano cele dotyczące nabywania nowych oraz rozwijania częściowo już ukonstytuowanych elementów kompetencji translacyjnej. Należy przy tym jeszcze raz podkreślić, iż jako prowadząca kurs byłam świadoma braku możliwości równoległego rozwijania pozostałych składowych kompetencji translacyjnej w ramach innych zajęć akademickich przewidzianych w programie studiów, w związku z czym w ramach cyklu założyłam rozwijanie jedynie jej wybranych elementów. Cele, które zostały sformułowane z myślą o zajęciach stacjonarnych i ich realizacji z wykorzystaniem tradycyjnych narzędzi i form dydaktycznych, były następujące:

1. rozwijanie kompetencji językowej na płaszczyznach leksykalnej, syntaktycznej oraz tekstualnej, głównie w zakresie języka ekonomii, języka prawnego oraz prawniczego;

2. rozwijanie wybranych elementów kompetencji translatorycznej, takich jak:

- kompetencja specjalistyczna, rozumiana jako wiedza specjalistyczna z zakresu ekonomii i prawa,

- kompetencja dyskursywna, rozumiana jako znajomość zasad tworzenia tekstów oraz ram i restrykcji dotyczących ich funkcjonowania w określonych dyskursach, w tym przypadku we współczesnym dyskursie ekonomicznym i prawniczym,

- kompetencja strategiczna, dotycząca odpowiedniego doboru i stosowania technik i strategii translatorskich w zależności od wymogów danego układu translacyjnego ${ }^{5}$.

Formami zajęć, zaplanowanymi w celu realizacji wymienionych celów z myślą o nauczaniu stacjonarnym, były przede wszystkim dyskusja dydaktyczna, rozumiana jako zorganizowana wymiana myśli i poglądów uczestników grupy na dany temat, praca indywidualna oraz praca w grupach o charakterze warsztatowym.

\footnotetext{
${ }^{5}$ Pojęcie układu translacyjnego w polskiej translatoryce jako pierwszy zastosował Grucza (1993). M odel układu translacyjnego jako układu komunikacyjnego stanowi realizację podnoszonego w ramach holistycznej teorii translacji postulatu całościowego postrzegania procesów przekładu, których centralnym elementem pozostaje tłumacz, a wszelkie jego decyzje i działania winny podlegać analizie i opisowi z uwzględnieniem wszystkich czynników konstytuujących i warunkujących te procesy. Należy do nich zaliczyć nie tylko ożywionych uczestników komunikacji - inicjatora, twórcę, prezentera tekstu wyjściowego oraz adresatów i użytkowników tekstu docelowego - lecz również elementy ich spajające, czyli wysyłane i odbierane przez obie strony komunikaty w postaci ustnych bądź pisemnych tekstów wyjściowego i docelowego.
} 
Przedyskutujmy to na forum - czyli o zdalnym rozwijaniu wybranych elementów...

\section{Organizacja zajęć zdalnych z wykorzystaniem forum dyskusyjnego}

Pierwsze dwa spotkania zrealizowano w formie tradycyjnej jako zajęcia stacjonarne. Były one poświęcone przede wszystkim rozwijaniu kompetencji językowej oraz specjalistycznej. Podczas dyskusji dydaktycznej utrwalono i rozszerzono wiedzę nabytą częściowo w ramach wykładów oraz konwersatoriów dotyczących specyfiki języków specjalistycznych, zawężając przy tym obszar zainteresowania do uwarunkowań funkcjonowania tekstów ekonomicznych, prawnych i prawniczych. Kolejnym etapem była praca z wykorzystaniem tekstów paralelnych ${ }^{6}$, których analiza i konfrontacja pozwoliły na zdobycie wiedzy na temat norm dotyczących wybranych wzorców tekstowych oraz ich mikroi makrotekstualnych wyróżników.

W związku z wprowadzanymi stopniowo obostrzeniami, spowodowanymi pandemią koronawirusa, po zrealizowaniu opisanych spotkań dydaktyka akademicka realizowana na UMCS w Lublinie była kontynuowana w formie zdalnej. W tej sytuacji kilka kolejnych spotkań zostało zrealizowanych za pomocą poczty elektronicznej i komunikatorów internetowych, a także testów oraz zadań otwartych dostępnych jako narzędzia dydaktyczne na funkcjonującej od 2004 roku platformie edukacyjnej Wirtualny Kampus UMCS. Na tym etapie studenci pracowali indywidualnie, wykonując pisemne ćwiczenia rozwijające ich kompetencję językową w zakresie leksyki specjalistycznej oraz typowych struktur syntaktycznych, a także sporządzając pisemne tłumaczenia krótkich tekstów informacyjnych, związanych tematycznie z materiałem, który miał być głównym przedmiotem pracy warsztatowej.

Po tak zrealizowanym etapie przygotowania możliwe było rozpoczęcie pracy warsztatowej. Słuchacze mieli pracować nad tłumaczeniem autentycznych tekstów niemieckojęzycznych funkcjonujących w dyskursie ekonomicznym i prawniczym. Pierwszym z nich była umowa o pracę, kolejnym zawarta w formie aktu notarialnego umowa spółki. Za najodpowiedniejszą formę realizacji założonych celów, pozwalającą w przestrzeni internetowej utworzyć formę pracy najbliższą warsztatom w grupach, uznałam forum dyskusyjne, dostępne, podobnie jak inne wcześniej wykorzystane narzędzia dydaktyczne, na platformie e-learningowej Wirtualny Kampus UMCS. Forum internetowe jest popularnym narzędziem w e-learningu na wielu poziomach edukacyjnych, otwierającym cały wachlarz zastosowań, również w kształceniu tłumaczy (zob.

\footnotetext{
${ }^{6}$ Według Krzysztoforskiej-Weisswasser (1995: 18 i n.) za teksty paralelne należy uznać „tekst[y] tego samego typu na ten sam temat, które powstały w takiej samej sytuacji komunikacyjnej", natomiast Šarčević (1999: 104) definiuje je jako równoprawne wersje językowe tekstów normatywnych.
} 
Krajka, M arczak, 2017), lecz w pewnych kontekstach wykazującym również ograniczenia (zob. m.in. Hanna, de Nooy, 2003; Sala 2009; Sucha, Engelhardt, Sarikas 2013). Za wyborem tego narzędzia jako najodpowiedniejszego w przypadku zaplanowanej formy zajęć przemawia szereg argumentów. Po pierwsze praca z nim umożliwia aktywną interakcję wszystkich studentów poprzez swobodne i nieograniczone publikowanie informacji i opinii, inicjowanie nowych dyskusji, publikowanie plików tekstowych i graficznych w różnych formatach, a także komentowanie wpisów innych użytkowników. Zdrugiej strony asynchroniczność forum internetowego (Plant, 2004) pozwala - w odróżnieniu do podobnych narzędzi dydaktyki zdalnej, np. wirtualnego pokoju, czatu czy wiki, rozłożyć w czasie pracę własną, a także z pewnym opóźnieniem reagować na wpisy pozostałych użytkowników. Przyczynia się to do bardziej przemyślanej i wartościowej merytorycznie dyskusji. Możliwość nie natychmiastowej, niewymuszonej reakcji online warunkuje ponadto zaistnienie tak zwanego online disinhibition effect (Suler, 2000), czyli w znacznym stopniu zmniejsza zahamowania, zwłaszcza u osób nieśmiałych.

W przypadku pracy z tłumaczonymi tekstami organizacja pracy wyglądała podobnie. W obu przypadkach grupa studentów uczestniczących w kursie została losowo podzielona na trzy zespoły, odpowiedzialne za tłumaczenie trzech kolejnych części tego samego tekstu. Następnie w każdym z trzech zespołów nastąpił dalszy podział materiału na mniejsze fragmenty, których liczba odpowiadała liczbie osób w grupie. W ten sposób każdy student otrzymał fragment tekstu, za który odpowiadał publikując w nowym wątku swoją, roboczą wersję tłumaczenia i tym samym otwierając dyskusję. Jego zadaniem było również bieżące dokonywanie korekt oraz opracowanie ostatecznej wersji przekładu. Oprócz pracy nad „swoim” fragmentem, zadaniem każdego uczestnika była również współpraca z grupą nad doskonaleniem części, za które odpowiadali koledzy.

Na pracę każdy zespół otrzymał dwa tygodnie. Prowadząca nie narzucała wyboru języka konsultacji wewnątrz grupy. Przez cały okres pozostawała w roli uważnego, lecz biernego obserwatora, na bieżąco śledząc rozwój dyskusji we wszystkich grupach, wykonując notatki, lecz nie ingerując w podejmowane decyzje. Dopiero po upływie czasu przeznaczonego na pracę na forum w obu przypadkach odbyło się spotkanie online, podczas którego prowadząca omówiła rozwój dyskusji, ustosunkowała się do poszczególnych wpisów, popierając właściwe rozwiązania, korygując błędne, lub też sugerując rozwikłanie napotkanych problemów tłumaczeniowych, z którymi grupa nie była w stanie poradzić sobie samodzielnie. Po naniesieniu ostatecznych korekt na poszczególnych fragmentach połączono je w jeden plik, dostępny dla całej grupy konwersatoryjnej. Ten sam schemat pracy został powtórzony podczas 
Przedyskutujmy to na forum - czyli o zdalnym rozwijaniu wybranych elementów...

tłumaczenia kolejnego tekstu, przy czym dokonano nowego, losowego podziału na zespoły robocze.

Pod względem ilościowym dynamika pracy na forum w przypadku obu tekstów wyglądała podobnie. Dwudziestodwuosobowa grupa zamieściła na forum łącznie 124 w pisy dotyczące pierwszego oraz 125 wpisów odnośnie drugiego tekstu. Każdy ze studentów opublikował przynajmniej cztery komentarze, przy czym większą aktywnością na forum wykazywały się osoby aktywniejsze również podczas zajęć stacjonarnych ${ }^{7}$. Odzwierciedlają to częściowo ilościowe różnice w liczbie wpisów w poszczególnych wątkach, przedstawione w poniższej tabeli.

\begin{tabular}{|l|l|r|r|r|}
\hline \multicolumn{2}{|c|}{} & ZESPÓ I & ZESPÓ II & Z्ESPÓ IIII \\
\hline \multirow{2}{*}{ LICZBA WPISÓW NA FORUM } & tekst 1 & 23 & 29 & 72 \\
\cline { 2 - 6 } & tekst 2 & 52 & 33 & 40 \\
\hline
\end{tabular}

Tabela 1: Liczba wpisów na forum w poszczególnych zespołach.

Zaobserwowano natomiast różnice pod względem wartości merytorycznej komentarzy publikowanych na poszczególnych forach. Podczas pracy nad pierwszym tekstem studenci publikowali głównie w języku niemieckim, w komentarzach wyrażając najczęściej swoje uznanie dla propozycji przekładu inicjatora wątku i pozwalając sobie jedynie na niewielkie korekty pierwotnej wersji tłumaczenia (przykłady 1 i 2):

1. Hallo Ola, Deine Übersetzung gefällt mir sehr ;) Meiner M einung alles top:) ${ }^{8}$

2. Karolina, Deine Übersetzung gefällt mir sehr :) Ich hab aber nur einen Vorschlag für Dich: statt Spółka ma jednego lub więcej dyrektorów, würde ich persönlich schreiben: „spółka posiada jednego lub więcej dyrektorów“

Zachowanie takie można uzasadnić traktowaniem pracy na forum jako swego rodzaju sprawdzianu z PNJN, obawami przed oceną ze strony prowadzącej lub też przed potraktowaniem własnej krytyki jako ataku i braku solidarności w stosunku do kolegów z grupy. W drugim etapie - po ustnym podsumowaniu pracy nad pierwszym tekstem - uczestnicy zamieszczali na forum komentarze w języku polskim, wyrażając w nich konstruktywną krytykę oraz liczne sugestie korekt, których przykłady zostaną przytoczone w kolejnym punkcie.

\footnotetext{
${ }^{7}$ Prawidłowość ta nie dotyczy jednak osób mniej aktywnych na zajęciach stacjonarnych, które w formie zdalnej znaczniej aktywniej uczestniczyły w dyskusji. Aspekt ten jest przedmiotem rozważań w punkcie 5.

${ }^{8}$ We wszystkich cytowanych przykładach zachowano oryginalną pisownię oraz interpunkcję.
} 


\section{Ocena realizacji założonych celów dydaktycznych}

Dokonując ewaluacji zrealizowanych zajęć pod koniec pierwszego semestru pracy zdalnej, postawiłam sobie przede wszystkim pytania:

- w jakim stopniu prowadząc zajęcia na odległość udało mi się osiągnąć cele dydaktyczne określone dla zajęć stacjonarnych,

- w jakim stopniu wymuszony nieoczekiwanie dystans fizyczny negatywnie wpłynął na dynamikę i efekty pracy w grupie studenckiej,

- w jakim stopniu dostępne technologie informatyczne pozwoliły te straty zrekompensować.

Wskutek autoewaluacji wyciągnęłam wnioski przedstawione poniżej.

Pomimo oczywistych ograniczeń w zakresie bezpośredniego kontaktu i interakcji, grupowa praca na forum, poprzedzona odpowiednim przygotowaniem językowym i merytorycznym, w dużym stopniu pozwoliła osiągnąć u słuchaczy kursu założone na początku cyklu cele dydaktyczne, którymi były wzbogacenie wiedzy i nabycie nowych umiejętności konstytuujących wybrane składowe kompetencji translacyjnej.

\section{KOM PETENCJA J ĘZYKOWA I DYSKURSYWNA}

Po przedstawieniu wersji roboczej tłumaczenia danego fragmentu w przeważającej większości wątków wywiązywała się dyskusja dotycząca terminologii lub struktury tekstu. Studenci wspólnie szukali najlepszego rozwiązznia, sięgając przy tym rzadziej do słowników, częściej do tekstów paralelnych, poszukując w nich pewnych powtarzalnych zasad i prawidłowości, np:

3. Bardzo trafne $s q$ uwagi Alicji, również dokonałbym poprawek w tych miejscach. „Pracownik otrzyma za pracę określonq w umowie” oraz świadczenie rzeczowe - ta konfiguracja jest zdecydowanie lepsza. Zgodniez przepisami kodeksu pracy, używa się częściej sformułowanie - świadczenie rzeczowe.

4. W drugim akapicie zamiast dodatek urlopowy napisałabym świadczenie urlopowe. Takie określenie znalazłam w polskiej umowie o pracę. A tak to nie mam uwag :)

5. "uchybić" moim zdaniem tu totalnie nie pasuje, ten czasownik chyba ma inne znaczenie, więc proponuję „naruszyć. Ale mogę się mylić.

Zauważono również dużą wrażliwość na poprawność językową w języku polskim - w wielu wątkach pojawiały się uwagi dotyczące warstwy stylistycznej, literówek, poprawnej pisowni oraz interpunkcji: 
Przedyskutujmy to na forum - czyli o zdalnym rozwijaniu wybranych elementów...

6. Hej Sara, a czemu tak pokombinowałaś z negacja? „że spółka nie powstaje, dopóki nie zostanie wpisana do rejestru handlowego", nie lepiej, „że spótka powstaje z chwilq wpisu do rejestru"?

7. „pozasqdowy” wird zusammen geschrieben.

8. Kasia, ich habe eine Kleinigkeit und zwar geht es mir um den 2. Satz. Auf polnisch wuerde ich eher sagen „odstapić od czegos" also es fehlt mir das Wort „od“: w przypadku odstapienia od udziału.....

9. Czy gramatycznie poprawnie będzie "musi być niezwłocznie zgłoszone”, czy może w liczbie mnogiej „musza być zgłoszone”? Z tego co pamiętam z gramatyki to sq to podmioty szeregowe, czyli powinno być też orzeczenie w liczbie mnogiej, które odnosi się do każdego elementu podmiotu.

\section{KOM PETENCJA SPECJALISTYCZNA}

Część problemów tłumaczeniowych wymagało analizy nie tylko tekstów paralelnych, ale również tekstów źródłowych z dziedziny prawa i ekonomii (przykłady 3 i 4). Dodatkowo w dwóch grupach znalazły się osoby równolegle studiujące prawo, które kilkakrotnie wyjaśniały wątpliwości terminologiczne, odwołując się do swojej wiedzy specjalistycznej i wyjaśniając na przykład różnice pomiędzy "sygnatariuszem" a "prokurentem", czy też uzasadnioną głównie uzusem językowym poprawność terminu "stawający":

10. Prokurist przetłumaczyłbym jako prokurent, [...]. Prokurent zajmuje się reprezentacja spółki pod czas dokonywania przezjej zarząd cynności prawnych; może być to tylko osoba fizyczna posiadajqca pełnq zdolność do cynności prawnych. Natomiast pojęcie sygnatariusza jest szersze i sq z nim zwiqzzane inne funkcje, ponieważ można tak nazwać zarówno państwo zawierajace międzynarodowe porozumienie lub traktat, jaki osobę upoważniona do podpisania umowy międzynarodowej lub osobę podpisująca umowę, oświadczenie lub memoriat:)

11. Ale nie wiem jak lepiej przetłumaczyć „dem Erschienenen”. „Powyższe pismo zostało odczytane, zatwierdzone oraz własnoręcznie podpisane w obecności notariusza przez osobę zainteresowanq / przez interesanta? [...]

- Wiesz co, stawajqcy to jest taki termin i on nie może być za bardzo zmieniony, to osoba, która się stawiła przed notariuszem.

Zaangażowanie w dyskusję osób, które można nazwać „specjalistami” w zakresie danej dziedziny, było dla pozostałych uczestników kursu istotnym potwierdzeniem znaczenia wiedzy specjalistycznej w procesie przekładu. M ożna założyć, że po takim doświadczeniu również w przyszłości będą korzystać z tej istotnej strategii tłumaczeniowej, jaką jest zasięgnięcie konsultacji specjalisty. 
12. Lepiej by brzmiało, gdyby „poświadczam/potwierdzam” stało na poczq̨tku? Oliwier tu musiałby się wypowiedzieć jak to wygląda w takiej dokumentacji, ale moim zdaniem raczej właśnie na poczqtku.

\section{KOM PETENCJA STRATEGICZNA}

Obok wspomnianej strategii konsultowania problemów tłumaczeniowych ze specjalistami oraz wykorzystywania tekstów paralelnych i źródłowych, studenci sięgali też do nabytej na etapie przygotowania wiedzy dotyczącej takich strategii translatorskich, jak kompensacja, eksplikacja, parafraza, kompresowanie i rozszerzanie tekstu czy stosowanie przypisów tłumacza:

13. M oże warto by było trochę zmienić kolejność, aby lepiej to brzmiało?

14. Agato! [...] A w ostatnim wersie dałbym po prostu kalkę, którq bardziej się stosuje u notariusza, czyli: Treść powyższego/tego dokumentu jest mi znana. Ew entualnie zapoznałem zamiast zaznajomiłem w Twojej wersji.

15. Obwieszczenia spótki sq publikowane w Monitorze Federalnym /(Federalnym Dzienniku Urzędowym) - a może warto byłoby tu dodać w nawiasie również niemieckq nazwę?

16. w pierwszym fragmencie rozwinęłabym ten skrót ArbZG lub przetłumaczyła go na polski a w nawiasie dałabym przyp. tłum.

\section{Dodatkowe wnioski}

Oprócz realizacji celów dydaktycznych założonych przed rozpoczęciem kursu, zajęcia przeprowadzone zdalnie z wykorzystaniem forum dyskusyjnego okazały się rozwijać u studentów również szereg dodatkowych umiejętności. Większość z nich to składowe kompetencji translacyjnej, wymieniane również we wspomnianym wcześniej programie kształcenia tłumaczy EMT (Toudic \& Krause, 2017), i zlokalizowane w różnych obszarach kompetencyjnych:

- w obszarze kompetencji tłumaczeniowej usytuować można: świadomość własnych słabych stron, konieczność samokontroli i autokorekty własnego przekładu, konieczność poddania się ocenie innych, umiejętność radzenia sobie z krytyką, a także: asertywność oraz umiejętność wykonywania prac o charakterze redakcyjnym i korektorskim;

- w obszarze kompetencji technicznej studenci obok oczywistego wykorzystania platform do nauczania zdalnego, rozwinęli umiejętność właściwego doboru i korzystania ze źródeł internetowych, baz danych oraz platform wymiany doświadczeń dla tłumaczy; 
- w obszarze kompetencji personalnych i interpersonalnych, lub też "soft skills", znajduje się bez wątpienia umiejętność samodzielnego zarządzania własnym czasem i nakładem pracy; do grupy kompetencji miękkich należy zaliczyć również umiejętność funkcjonowania w zespole, w tym przypadku w zespole wirtualnym z wykorzystaniem w tym celu niezbędnych technologii ICT.

Istotny i wart podkreślenia jest również wpływ, jaki przeniesienie zajęć z sali wykładowej do przestrzeni wirtualnej wywarło na dynamikę pracy w grupie i aktywizację studentów. Wykorzystanie forum dyskusyjnego jako narzędzia dydaktycznego budziło we mnie wiele obaw, zwłaszcza odnośnie do możliwości odpowiedniego zaktywizowania wszystkich uczestników kursu. Należy tutaj nadmienić, że grupa słuchaczy, aktywność, sposób pracy i typy temperamentalne poszczególnych osób były mi dobrze znane z wcześniej prowadzonych zajęć stacjonarnych, co uzasadniało moje obawy. Dokładny podział zakresu odpowiedzialności miał wyeliminować/ograniczyć różnice w aktywności słuchaczy, jednak nie dawał gwarancji, iż osoby mniej aktywne poza wykonaniem obligatoryjnej części zadania, czyli pracą nad swoim fragmentem tekstu, faktycznie zaangażują się w dyskusje dotyczące innych wątków. Tymczasem z zaskoczeniem obserwowałam pozytywny wpływ, jaki zdalna forma pracy na forum dyskusyjnym wywiera na studentów, których typ osobowości wyglądał na introwertyczny. Osoby te częściej i z większą pewnością siebie niż na zajęciach stacjonarnych zabierały głos w trwających już dyskusjach, a nawet inicjowały interakcje na forum. Nie oznacza to, że były one aktywniejsze niż studenci, którzy przyzwyczaili już prowadzących do swojej dominującej roli w grupie (ci w wielu przypadkach również na forum dyskusyjnym zabierali głos najczęściej), jednak ich aktywność była zdecydowanie większa niż na zajęciach stacjonarnych. Narzucone zasadami forum dyskusyjnego ograniczenie wszystkich wypowiedzi wyłącznie do formy pisemnej, bez wzmocnienia w postaci gestykulacji, siły głosu czy po prostu ekstrawertycznego sposobu bycia, pozwoliły zabrać głos każdemu, a grupie skoncentrować się wyłącznie na merytorycznej stronie wypowiedzi. Mówiąc potocznie - nikt nie został "zakrzyczany”. A zatem dystans fizyczny jako centralny i najczęściej krytykowany element dydaktyki zdalnej w obserwowanej przeze mnie grupie studenckiej okazał się czynnikiem pozytywnie wpływającym na funkcjonowanie w niej, zwłaszcza studentów nieco wycofanych i przez to mniej aktywnych na zajęciach stacjonarnych.

Kolejnym czynnikiem, który miał pozytywny wpływ zwłaszcza na pracę mniej aktywnych studentów, była asynchroniczność forum internetowego, pozwalająca na samodzielne zarządzanie czasem pracy i umożliwiająca dodawanie komentarzy w dowolnym momencie. Jest to bez wątpienia również związane 
z cechami osobowościowymi osób bardziej wycofanych, które nie reagują impulsywnie i znacznie dłużej analizują swoje wypowiedzi. Dynamika interakcji w grupie na zajęciach stacjonarnych jest na tyle duża, że osoby takie często nie dysponują wystarczającą ilością czasu, żeby zaproponować własne - nierzadko lepsze niż te spontaniczne - rozwiązania. Natomiast wydłużony czas, jaki studenci otrzymali na opracowanie tłumaczeń na forum, każdemu z nich dawał możliwość przedstawienia własnego zdania w najbardziej dogodnym dla niego momencie.

\section{Podsumowanie}

Podsumowując, należy stwierdzić, że forum dyskusyjne stanowi cenne narzędzie dydaktyczne, pozwalające na rozwijanie wielu elementów kompetencji translacyjnej w stopniu zbliżonym do zajęć stacjonarnych, czego dowodem mogą być przytoczone powyżej przykłady. Do jego głównych walorów należy niewątpliwie asynchroniczność i związana z nią większa przystępność dla osób mniej impulsywnych i bardziej wycofanych, jak również możliwość bieżącego i nieograniczonego wglądu prowadzącego w proces dyskusji nad propozycjami tłumaczeń i wyborem strategii tłumaczeniowych we wszystkich zespołach, który w pracy stacjonarnej z przyczyn oczywistych ma charakter wybiórczy. Patrząc krytycznie na cykl zajęć nie można pominąć również pewnych - nie tylko tych antycypowanych przeze mnie - ograniczeń i trudności związanych z ich zdalną organizacją. Obok wspominanego na wstępie dystansu fizycznego i braku możliwości bezpośredniej interakcji pomiędzy samymi studentami, a także grupą i prowadzącą, które były odczuwalne zwłaszcza dla osób o bardziej ekstrawertycznych typach osobowości, problematyczny okazał się również brak możliwości kontroli nad właściwym doborem i wykorzystaniem źródeł internetowych oraz tekstów źródłowych, mogący prowadzić do wykształcenia błędnych nawyków. Ztego względu wydaje się, że optymalne wykorzystanie potencjału dydaktycznego forum internetowego zapewniłaby hybrydowa organizacja cyklu podobnych zajęć, pozwalająca w sposób zdalny realizować wybrane cele dydaktyczne i dostosować formy pracy do potrzeb studentów o różnych typach osobowości.

\section{BIBLIOGRAFIA}

Grucza F. (1981), Zagadnienia translatoryki, (w:) Grucza F. (red.), Glottodydaktyka a translatoryka, Materiały z IV Sympozjum Instytutu Lingwistyki Stosowanej. Warszawa: WUW, s. 9-27.

Grucza F. (1993), Interkulturelle Translationskompetenz: Ihre Struktur und Natur, (w:) Frank A.P., M aaß K. J., Paul F., Türk H. (red.), Übersetzen, verstehen, Brücken bauen. Berlin: Erich Schmidt Verlag, s. 158-171. 
Przedyskutujmy to na forum - czyli o zdalnym rozwijaniu wybranych elementów...

Grucza F. (2008), Germanistische Translatorik - ihr Gegenstand und ihre Aufgaben, (w:), Grucza F. (red.), Translatorik in Forschung und Lehre der Germanistik. Warszawa: Euro-Edukacja, s. 27-53.

Hansen G. (1998), Die Rolle der fremdsprachlichen Kompetenz, (w:) SnellHornby M., Hönig H.G., Kussmaul P., Schmitt P.A. (red.), Handbuch Translation. Tybinga: Stauffenburg Verlag, s. 341-342.

Hanna B.E., de Nooy J. (2003), A funny thing happened on the way to the forum: electronic discussion and foreign language learning. "Language Learning \& Technology", 7 (1), s. 71-82.

Hejwowski K. (2004), Kognitywno-komunikacyjna teoria przekładu. Warszawa: Wydawnictwo Naukowe PWN.

Kautz U. (2000), Handbuch Didaktik des Übersetzens und Dolmetschens, M onachium: Iudicum/Goethe-Institut.

Kelly D. (2005), A Handbook for Translator Trainers. M anchester: St. Jerome Publishing.

Kościałkowska-Okońska E. (2013), Dydaktyka przekładu tekstów specjalistycznych w kontekście rozwoju kompetencji tumaczeniowej. „Rocznik Przekładoznawczy. Studia nad teorią, praktyką i dydaktyką przekładu", 8, s. 137-155. Krajka J., M arczak M . (2017), Telecollaboration projects in translator education - Design, implementation and evaluation, (w:) Smyrnova-Trybulska E. (red.), Effective development of teachers' skills in the area of ICT and elearning. Cieszyn: University of Silesia/Noa, s. 365-388.

Krzysztoforska-Weisswasser Z. (1995), Zbiór dokumentów polskich dla tłumaczy przysięgłych. Częstochowa.

M ałgorzewicz A. (2012), Die Kompetenzen des Translators aus kognitiver und translationsdidaktischer Sicht. Wrocław: Wydawnictwo Uniwersytetu Wrocławskiego.

M ałgorzewicz A. (2014), Językowe i niejęzykowe kompetencje tłumacza. Próba zdefiniowania celów translodydaktyki akademickiej. „Lingwistyka Stosowana", 11, s. 1-10.

Małgorzewicz A. (2019), Universitäre postgraduale Translatorenausbildung strategische Konzepte, Praxiserfahrungen und Ergebnisse. „Germanica Wratislaviensia", 144, s. 185-197.

M archwiński A. (1992), Kompetencja kulturowa a kompetencja translatorska. Implikacje dydaktyczne, (w:) Grucza F. (red.), Gramatyka - konstrukt intelektualny czy rzeczywistość: glottodydaktyczne implikacje tej alternatywy. Warszawa: WUW, s. 243-255.

Marchwiński A. (2010), O pewnym aspekcie dydaktyki translacji, (w:) Grucza S., Marchwiński A., Płużyczka M. (red.), Translatoryka. Koncepcje - modele - analizy. Warszawa: Wydział Lingwistyki Stosowanej, Uniwersytet Warszawski, s. 339-348. 
Nord Ch. (1988), Textanalyse und Übersetzen. Theoretische Grundlagen, M ethode und didaktische Anwendung einer übersetzungsrelevanten Textanalyse. Heidelberg: Groos.

Plant R. (2004), Online communities. "Technology in Society", 26 (1), s. 51-65. Pöchhacker F. (2001), Dolmetschen und translatorische Kompetenz, (w:). Kelletat A. F (red.), Dolmetschen: Beiträge aus Forschung, Lehre und Praxis. Frankfurt: Peter Lang. s. 19-37.

Pym A. (2003), Redefining Translation Competence in an Electronic Age: In Defence of a Minimalist Approach, "M eta: Translators' Journal", 48 (4), s. 481-497.

Resch R. (1998), Die Rolle der muttersprachlichen Kompetenz, (w:) SnellHornby M., Hönig H.G., Kussmaul P., Schmitt P.A. (red.), Handbuch Translation. Tybinga: Stauffenburg Verlag, s. 343-345.

Sala W. (2009), Supporting the Education Process in Secondary School by Distance Learning, (w:) Smyrnova-Trybulska E. (red.), Theoretical and Practical Aspects of Distance Learning. Cieszyn: University of Silesia, s. 180-188.

Šarčević S. (1999), Das Übersetzen normativer Rechtstexte, (w:) Sandrini P. (red.), Übersetzen von Rechtstexten. Fachkommunikation im Spannungsfeld zwischen Rechtsordnung und Sprache. Tybinga: Narr, s. 103-118.

Sucha M ., Engelhardt S., Sarikas A. (2013), Internet discussion forums as part of a student-centred teaching concept of pharmacology. "GM S Journal for Medical Education", 30. Online: https://www.egms.de/static/en/ journals/zma/2013-30/zma000845.shtml [DW 20.04.2021].

Suler J. (2004), The online disinhibition effect. "Cyber Psychology \& Behavior", 7 (3), s. 321-326.

Toudic D., Krause A. (2017), European Master's in Translation - Kompetenzrahmen 2017 Online: https://ec.europa.eu/info/sites/default/files /emt_competence_fwk_2017_de_web.pdf [DW 28.04.2021].

Way Ch. (2008), Systematic Assessment of Translator Competence: In Search of Achilles' Heel, (w:) Kearns J. (red.), Translator and Interpreter Training: Issues, Methods and Debates. Londyn: Continuum, s. 88-102.

Witte H. (1998), Die Rolle der Kulturkompetenz, (w:) Snell-Hornby M., Hönig H.G., Kussmaul P., Schmitt P.A. (red.), Handbuch Translation. Tybinga: Stauffenburg Verlag, s. 345-348.

Żmudzki J. (2010), Aktuelle Profile der germanistischen Translationsdidaktik in Polen, (w:) Małgorzewicz A. (red.), Translation: Theorie - Praxis - Didaktik. Drezno/Wrocław: Neisse Verlag/Oficyna Wydawnicza ATUT, s. 117-136. 